\title{
François Hollandes Frankrig
}

Erling Bjøl

Hollande står over for enorme udfordringer. Han ved, at han må slå ind på nogle af de trange stier, som det tyske socialdemokrati har betrådt, men han ved også at det koster at rette skuden op, og det kan allerede spores i meningsmålingerne

Frankrigs første socialdemokratiske præsident har dets mest erfarne politiske analytiker Alain Duhamel kaldt François Hollande. Til forskel fra François Mitterrand, der blev valgt i 1981. Han blev betragtet som socialist, og i det mindste gik han i gang med et omfattende nationaliseringsprogram.

Socialdemokrater har dog før haft del i magten. I 1988 bad Mitterrand sin rival inden for partiet, Michel Rocard, om at danne regering, efter at socialisterne havde mistet flertallet i Nationalforsamlingen. Rocard, som ikke var bange for at kalde sig socialdemokrat, dannede en koalition hen over midten. De tre år, han sad ved magten, indtil Mitterrand skilte sig af med ham, blev en af de mest frugtbare reformperioder $\mathrm{i}$ den femte Republik. Den er på flere måder referenceramme for den politik, som Hollande har lagt op til.
Hollande har direkte bekendt sig til Rocard ved at skrive forordet til en bog, som Rocard udsendte under valgkampen i foråret, Mes points sur les $i$. Den indeholder bl.a. gode råd om, hvordan man skal få listet reformer igennem så sprælsk og konservativt et samfund som det franske.

Som forbillede nævner han sine egne reformer af Air France, Renault og postvæsenet. Selv præsenterede Rocard op til præsidentvalget $\mathrm{i}$ 2007 Mogens Lykketofts Le modèle danois. For det er de nordiske lande, sejlsportsmanden Rocard har haft særligt blik for. Han var i mange år borgmester i pramskippernes hovedstad, Conflans-Sainte-Honorine.

\section{Fra Mitterrand til Hollande}

Mitterrand selv var med Rocard ved roret helt optaget af den internationale politik, der medførte så store 
omvæltninger, ikke mindst takket være ham selv. Først og fremmest Tysklands genforening, vedtagelsen af Maastricht-traktaten og afslutningen af den kolde krig. Der synes at have udviklet sig et oprigtigt venskab mellem Mitterrand og Helmut Kohl. De havde begge haft dystre krigsoplevelser under Anden Verdenskrig.

Men genforeningen blev en tungere økonomisk belastning, end Kohl havde regnet med, og Tyskland blev som Bernard de Montferrand, fransk ambassadør i Tyskland 20072011, skriver i sin bog France-Allemagne: l'heure de vérité (Éditions Tallandier, 2011) noget af et 'Jammerland'.

Den økonomiske vækst stilnede af. Arbejdsløsheden steg. Kapitalen søgte ud af landet, ikke mindst til andre europæiske lande. Indtil socialdemokraterne kom til magten med Gerhard Schröder, som søsatte det dristige reformprogram Agenda 2010, der skulle forbedre Tysklands konkurrenceevne på eksportmarkederne. Det indebar bl.a. nogle banebrydende reformer af arbejdsmarkedet, som kom til at skabe en enestående fleksibilitet. Det kom til at koste Schröder magten i 2005, så det først blev Angela Merkels store koalition med socialdemokraterne, som begyndte at få glæde af reformerne og endnu mere hendes koalition med FDP efter 2009.

I Frankring mente Lionel Jospins socialistiske regering imidlertid at kunne flotte sig med indførelse af
35 timers arbejdsuge, 60 års pensionsalder og andet godt i stedet for at bruge det overskud, man tilmed fik på finansloven, kendt som la cagnotte, spillepuljen, til at betale af på den enorme gæld, som Frankrig havde ophobet siden oliekrisen i 1974, der gjorde ende på den tid, man i Frankrig kalder les trente glorieuses, de 30 glorværdige år efter befrielsen i 1944.

Selv om præsident Jacques Chirac var gaullist, lod han stå til. Han havde selv prøvet at få gennemført nødvendige, men upopulære reformer, da han var blevet valgt i 1995. Det førte til, at socialisterne vandt, da han udskrev parlamentsvalg. Han ville selv gerne genvælges til præsident i 2002. Det lykkedes ham faktisk i anden runde ved hjælp af socialistiske stemmer, da Jospin trods sine velgerninger blev slået på andenpladsen i første omgang af $h ø j-$ reekstremisten Jean-Marie Le Pen med knap 250.000 stemmer, da Chirac var rykket for meget mod midten for at slå Jospin.

Chirac fik en flot anden periode på verdensscenen ved at gå imod George W. Bushs krig i Irak. I modsætning til ham og de andre krigsvillige vidste Chirac, hvad der ventede. Han havde selv været soldat i Algeriet under Frankrigs lange og tabte krig dernede.

Indadtil sørgede en fredsommelig radikal premierminister, Jean-Pierre Raffarin, for ro, men kom til at tabe folkeafstemningen om den europæ- 
iske forfatningstraktat i 2005 , da socialisterne var i opposition og for størstedelen stemte nej. Som en række indgående politologiske undersøgelser af de europæiske folkeafstemninger i Frankrig har vist, har det kun været en 15-20 pct. af vælgerne, som egentlig har stemt om selve traktaterne (jvf. Udenrigs, nr. 4, 2007).

Chiracs efterfølger Nicolas Sarkozy var så uheldig, at han blev ramt af den store internationale økonomiske krise et år efter at være blevet valgt og på et tidspunkt, hvor Frankrig var begyndt at sakke bagud for Tyskland. Frankrig blev hårdt ramt af afindustrialisering, voksende arbejdsløshed og stigende statsgæld. Da Sarkozy prøvede at blive genvalgt i 2012, fik man at vide af Tysklands toneangivende økonomiske vismand Hans Werner Sinn fra IFO i München, at landet måtte igennem 10 års Agenda-kur for igen at komme på højde med Tyskland i konkurrenceevne.

\section{'France in denial'}

The Economist vakte en del opsigt i Frankrig, da det under valgkampen udsendte et nummer med Manets berømte Frokost i det grønne på omslaget og titlen 'France in denial, The West's most frivolous election'.

Bladet indeholdt en analyse, som dets chefkorrespondent i Paris, Sophie Pedder, havde skrevet. Den har hun siden udvidet til en hel bog, som hun har skrevet på fransk og kaldt Le Deni français, den franske fornægtelse (af de økonomiske kendsgerninger) med undertitlen 'Europas forkælede barn'. Det er en dokumentation af, at Frankrig i 40 år har levet over evne ved at udvikle Europas mest generøse velfærdsstat på kredit.

Spørgsmålet er dog, om Frankrig ikke nu er ved at vågne op. Ambassadør Montferrand gav sin bog om Frankrig og Tyskland undertitlen 'sandhedens time', og da præsident François Hollande endelig efter lang tavshed i sit interview til den europæiske presse op til topmødet 18. oktober formulerede sin europæiske politik, var noget af det, han understregede netop, at Frankrigs store problem var, at statsgælden siden 2007 var vokset fra 62 til 90 pct. af BNP, højere end Spaniens.

Det var derfor afgørende at få underskuddet på næste års finanslov ned på 3 pct. Det kan ikke ske bare ved at forhøje skatterne. I forvejen går indtægterne fra de direkte skatter til forrentning af lån, som er blevet optaget siden midten af 1970'erne. Der må også besparelser til, især på de sociale budgetter, og det bliver en hård kamp, ikke mindst med regeringens eget flertal.

\section{Arven fra fortiden}

Her har Hollande en lang og tung venstrerevolutionær arv at trækkes med. Den går helt tilbage til borger- 
krigen i sommeren 1848, hvor Cavaignac nedslagtede 5.000 arbejdsløse, der havde fået job i de nyoprettede 'nationalværksteder', som den grundlovgivende forsamling havde besluttet at spare bort. "Junirevolutionen er den første, der for alvor deler hele samfundet i to fjendtlige lejre, som repræsenteres af Østparis og Vestparis", skrev Friedrich Engels. "Ingen er ligegyldig længere. Noget aldrig set før. Klassekampen som historiens drivhjul".

Klassekampen fik en ny blodig akt under Pariserkommunen, der satte lange spor. Så kom Første Verdenskrigs slagterier, der gjorde Lenin til den store helt, fordi han fik Rusland ud af krigen. I 1920 tilsluttede det franske socialistparti sig Tredje Internationale og tog partiorganet l'Humanité med sig. Under Anden Verdenskrig lykkedes det kommunisterne at få kontrol med den største faglige landsorganisation CGT, mens de socialistiske ledere sad i tyske koncentrationslejre. De fik også sat deres præg på det efterkrigsprogram, som blev vedtaget af det franske frihedsråd, Conseil National de la Résistance, og som ligger til grund for hele det kostbare velfærdssystem, som tynger det franske budget mere og mere. Samt alle de regler, der plager franske virksomheder, så snart de går over 50 ansatte. Selv efter Sovjetunionens sammenbrud lever det franske kommunistparti videre, i det mindste en gang om året, i september måned endda i bedste velgående, når det fylder partikassen med den populære folkefest de l'Humanité.

\section{Hollandes udfordringer}

De udfordringer, Hollande står overfor, er enorme. Men han har nok bedre forudsætninger for at klare dem end sin forgænger. I sit portræt af ham i Portraits souvenirs skriver Alain Duhamel:

"Der er to oplagte træk ved François Hollande. På den ene side at han umiddelbart vækker sympati, på den anden, at han bestandig er blevet undervurderet af sine kammerater. Paradoksalt, absurd. Men alligevel er det første nok en del af forklaringen for det sidste. En mand, der er afslappet, venlig, smilende og åben, tillægges hverken karisma, myndighed eller format. Man overser Hollande. Fordi han forekommer 'normal'. Men han er nok mere moderne end dem, der har overset ham".

Måske repræsenterer han en ny fase i den femte Republik, mere tolerant, mindre manikæisk. Han besidder både esprit og humor, en sjælden egenskab i det nuværende politiske liv i Frankrig. Munterhed anses nærmest for en dødssynd blandt partiets topfolk, ironi for uforenelig med alvor. Men det gør ham populær hos journalisterne. Mitterrand bemærkede engang om ham, at han virkelig besad 'esprit politique'. 
Han har også på en gang en solid uddannelse bag sig og et udbredt folkeligt kontaktnet. Han er ikke bare udgået fra den eksklusive forvaltningshøjskole Ecole Nationale d'Administration, hvor der undervises i beslutningstagning, men også gives points for faldskærmsudspring, men også fra Frankrigs Rigsrevision og har undervist i økonomi på det parisiske statskundskabsinstitut Ecole des Sciences Politiques.

Men han er vokset op i Rouen og valgt til Nationalforsamlingen fra Corrèze i hjertet af det franske kerneland. I de år, han var det socialistiske partis generalsekretær fra 1997 til 2008 var han bestandig på farten landet rundt med det hovedmål at holde sammen på det sprælske parti. Samtidig havde han et tæt samarbejde med Lionel Jospin, da han var blevet premierminister.

Ingen har haft bedre kontakt med de menige partimedlemmer. Men at der også er dybere strenge $i$ hans sind, kan man slutte af, at hans foretrukne vise er Leo Ferrés sørgmodige Avec le temps. Men at det ikke svækker hans kampmod, kan man måske slutte af, at den fyrrige belgier Jacques Brel ellers er hans favorit. Med tiden er han også blevet en af partiets bedste talere og debattører, der ikke er let at slå ud, og aldrig mister sin selvbeherskelse.

At han vandt præsidentvalget, er ikke gået ham til hovedet. Han er ikke flyttet ind i Elysée-palæet, men blevet boende hjemme i sin lejlig- hed. Når han ikke er på rejse, møder han dog hver morgen kl. 8.30 velforberedt op på sit kontor. For han har taget akterne med hjem om aftenen.

Grebet om partiet har Hollande sikret sig ved at få valgt sin egen kandidat Harlem Desir, af algiersk oprindelse, til ny partisekretær efter den mindre omgængelige Martine Aubry. Han fik 70 pct. af stemmerne i partiet. Men der er stadig en urolig venstrefløj, som Hollande har prøvet på at tæmme ved at gøre Arnaud Montebourg til minister for produktivitetsudvikling. For en af de store opgaver for at få Frankrig gjort konkurrencedygtigt igen bliver at få skabt større fleksibilitet på arbejdsmarkedet.

Her vil det komme til at spille en afgørende rolle, hvem der kommer til at efterfølge Bernard Thibault som generalsekretær for CGT. Han har lidt efter lidt udviklet en mere tidssvarende forhandlingskultur. Men hvor denne landsorganisation havner, vil først blive endeligt afgjort til foråret.

I mellemtiden forsøger Hollande at forberede reformerne på arbejdsmarkedet ved to- og trepartsforhandlinger. Men også arbejdsgiverforeningen skifter leder næste år.

Efter de foreløbige løsninger, der er fundet på de mest presserende problemer inden for EU, vil 2013 også blive kritisk. Herman van Rompuy vil have afleveret sin betænkning om Unionens fremtid. Det eu- 
ropæiske banktilsyns retsramme skal være klar, så man kan gå i gang med at udfylde den med henblik på oprettelsen af en europæisk bankunion.

\section{Forholdet til Tyskland}

Men først og fremmest skal der være valg i Tyskland. På flere områder kommer Hollande nok til at træde vande, indtil de er overstået. For det fransk-tyske forhold vil stadig være aksen i det europæiske samarbejde, selv om Hollande med sine planer om at få gang i den økonomiske vækst igen har knyttet kontakter med især Mario Monti i Italien, hvor der dog også skal være valg.

Forholdet til Tyskland vil forblive det centrale i fransk udenrigspolitik. Hollande selv gik imod hovedstrømmen inden for sit parti, da han ved folkeafstemningen om forfatningstraktaten i 2005 var for ja. Som regeringschef har han valgt en mand, der taler flydende tysk, Nantes' kreative borgmester Jean-Marc Ayrault. Men som Europaminister en nejsiger fra 2005, Bernard Cazeneuve, borgmester i Cherbourg, i en af de egne, der er mest afhængig af atomenergien, som tyskerne prøver at komme væk fra med deres Energiewende.

Fru Merkel gik under valgkampen åbent ind for Nicolas Sarkozy. Men hun var den første, Hollande besøgte, da han var blevet valgt, og de to har konstateret, at de, selv om de politisk er uenige på centrale områder som omfanget af suverænitetsafgivelse og fælleseuropæiske statsobligationer, svinger ganske godt sammen psykologisk ved et sindigt temperament og en veludviklet humoristisk sans. Small-talk fører de direkte på engelsk, mens alvorligere forretninger sker gennem tolk.

Men først og fremmest har Hollande etableret et nærmere samarbejde med de tyske socialdemokrater, end man tidligere har haft. Her møder han større forståelse for sin vægt på økonomisk vækst og europæisk solidaritet. Integration og solidaritet er Hollandes europæiske slagord.

Han er godt klar over, at han må slå ind på nogle af de trange stier, som det tyske socialdemokrati har betrådt. Han foretrækker dog at henvise til den svenske vej, som blev anvist af partifællen Göran Persson i 1990'erne. Vel for ikke at vække de nationalistiske dæmoner, som raser i Grækenland, men ikke hidtil har spillet nogen større rolle under krisen i Frankrig.

Han ved dog fra Gerhard Schröder, hvad det vil koste at rette skuden op, og det kan allerede spores i meningsmålingerne. Han understreger derfor gang på gang, at han ønsker at blive bedømt på sine resultater om fem år, og det tilføjes, at Schröder kom for sent i gang.

Erling Bjøl er professor emeritus, drscient.pol., historiker og journalist. 